\title{
Pengaruh Fasilitas Belajar, Minat Belajar, Lingkungan Belajar dan Motivasi Belajar terhadap Hasil Belajar Siswa pada Mata Pelajaran IPS SMK Kabupaten Tanah Datar: Kajian
}

\author{
Hayatul Azma ${ }^{1}$ \\ ${ }^{1}$ Guru SMK Negeri 1 Batusangkar
}

\begin{abstract}
This research is aimed to see: (1) The influence of learning facilities toward students learning motivation in social science subject of vocational schools in Tanah Datar Regency (2) The influence of learning interest toward students learning motivation in social science subject of vocational schools in Tanah Datar Regency (3) The influence of learning environment toward students learning motivation in social science subject of vocational schools in Tanah Datar Regency (4) The influence of learning facilities toward students learning achievement in social science subject of vocational schools in Tanah Datar Regency (5) The influence of learning interest toward students learning achievement in social science subject of vocational schools in Tanah Datar Regency (6) The influence of learning environment toward students learning achievement in social science subject of vocational schools in Tanah Datar Regency (7) The influence of learning motivation toward students learning achievement in social science subject of vocational schools in Tanah Datar Regency. The kind of this research is causal descriptive. The research population is all students at grade XI of vocational schools in Tanah Datar Regency. Number of the population is 750 students in 2016/2017 academic year. The sample was taken by using the technic of Proportional Random Sampling. The research sampling is 261 students out of the whole population. Primary data in this research is taken from questionnaire given to the respondents, and the secondary data, is related to the research object which is presented by other authorities in the form of students learning achievement in final semester examination (UAS) in social science subject. The technic of data analysis is path analysis with SPSS program 15.0 Version. The research findings are: (1) Learning facilities has significant influence toward students learning motivation in social science subject of vocational schools in Tanah Datar Regency (2) Learning interest has significant influence toward students learning motivation in social science subject of vocational schools in Tanah Datar Regency (3) Learning environment has significant influence toward students learning motivation in social science subject of vocational schools in Tanah Datar Regency (4) Learning facilities have significant influence toward students learning achievement in social science subject of vocational schools in Tanah Datar Regency(5) Learning interest has significant influence toward students learning achievement in social science subject of vocational schools in Tanah Datar Regency(6) Learning environment has significant influence toward students learning achievement in social science subject of vocational schools in Tanah Datar Regency(7) Learning motivation has significant influence toward students learning achievement in social science subject of vocational schools in Tanah Datar Regency.
\end{abstract}

Keywords: Learning Facilities, Learning Interest, Learning Environment, Learning Motivation, Toward Students

\section{PENDAHULUAN}

Selama proses belajar mengajar berlangsung, banyak faktor-faktor yang mempengaruhi hasil belajar siswa. Syah (2008:132) mengemukakan ada 3 faktor yang mempengaruhi hasil belajar, yaitu faktor internal siswa (terdiri dari kesehatan, intelegensi dan bakat, minat dan motivasi, sikap, dan cara belajar), faktor eksternal siswa (terdiri dari keluarga, sekolah, masyarakat, dan lingkungan belajar), serta faktor pendekatan belajar. Siswa akan memperoleh hasil belajar yang memuaskan, apabila faktor yang mempengaruhi hasil belajar tersebut dimiliki dan dimanfaatkan dengan baik. Namun sebaliknya, siswa akan memperoleh hasil yang kurang memuaskan, apabila faktor-faktor yang mempengaruhi hasil belajar tidak dimiliki dan dimanfaatkan dengan baik.

Sementara Purwanto (2003:107) menyatakan bahwa terdapat beberapa faktor yang mempengaruhi pencapaian hasil belajar siswa adalah :

1. Internal

a. Fisiologi meliputi: kondisifisik dan panca indra.

b. Psikologi meliputi: bakat dan minat, kecerdasan, motivasi dan kemampuan kognitif.

2. Eksternal

a. Lingkungan meliputi: lingkungan alam dan sosial.

b. Instrumental meliputi: kurikulum/materi, guru, sarana dan prasarana dan manajemen/ administrasi.
Berdasarkan uraian diatas dapat disimpulkan bahwa faktor-faktor yang mempengaruhi hasil belajar siswa diantaranya faktor internal siswa yang meliputi kesehatan, intelegensi dan bakat, minat dan motivasi, sikap, dan cara belajar, dan faktor eksternal siswa yang terdiri dari keluarga, sekolah, masyarakat, dan lingkungan belajar, serta faktor pendekatan belajar.

Ilmu Pengetahuan Sosial merupakan salah satu mata pelajaran yang penting yang diajarkan kepada siswa pada jenjang pendidikan SMK. Pada jenjang Sekolah Menengah Kejuruan (SMK), IPS menjadi mata pelajaran yang di dalamnya mencakup subbidang studi ekonomi, sejarah, sosiologi dan geografi. IPS di SMK diajarkan dengan alokasi waktu 2 jam pelajaran perminggu. Dengan alokasi waktu 2 jam per minggu tersebut siswa diharapkan dapat menguasai atau memahami materi IPS yang cukup kompleks

Berdasarkan hasil ujian tengah semester siswa kelas XI SMK Kabupaten Tanah datar dapat diperoleh informasi bahwa ketuntasan hasil belajar siswa untuk mata pelajaran IPS masih rendah. Penulis memperkirakan hal ini terjadi karena berkaitan dengan adanya faktor-faktor yang mempengaruhi hasil belajar siswa yang meliputi faktor internal siswa dan faktor eksternal siswa yang meliputi fasilitas penunjang proses pembelajaran, minat siswa, lingkungan belajar serta motivasi belajar pada mata pelajaran IPS yang masih belum maksimal.

Adapun tujuan penelitian ini adalah untuk mengetahui (1) Pengaruh fasilitas belajar (X1), minat belajar (X2), dan lingkungan belajar (X3) terhadap 
motivasi belajar siswa (X4) pada mata pelajaran IPS SMK Kabupaten Tanah Datar, dan (2) Pengaruh fasilitas belajar (X1), minat belajar (X2), lingkungan belajar (X3), dan motivasi belajar (X4) terhadap hasil belajar siswa (Y) pada mata pelajaran IPS SMK Kabupaten Tanah Datar.

\section{METODE PENELITIAN}

Jenis penelitian yang digunakan adalah deskriptif kausal. Populasi penelitian ini adalah seluruh siswa kelas XI SMK Kabupaten Tanah Datar yang berjumlah 750 orang siswa tahun ajaran 2016-2017. Sampel diambil dengan teknik proporsional random sampling. Sampel penelitian yang diambil berjumlah 261 orang siswa dari keseluruhan populasi. Data primer dalam penelitian ini diperoleh dari kuesioner/angket yang disebar kepada responden, sedangkan data sekunder yaitu data yang terkait dengan objek penelitian yang disajikan oleh pihak lain yaitu data hasil belajar siswa dari nilai ujian akhir semester (UAS) mata pelajaran IPS. Teknik analisis data yang dipakai dengan menggunakan analisis jalur dengan program SPSS Versi 15.0.

\section{HASIL DAN PEMBAHASAN}

Berdasarkan pengujian hipotesis maka dapat dilihat rekapitulasi pengaruh secara langsung maupun tidak langsung variabel penyebab terhadap variabel akibat pada tabel berikut ini:

Tabel 1. Rekapitulasi Pengaruh Variabel Penyebab Terhadap Variabel Akibat

\begin{tabular}{|c|c|c|c|}
\hline No. & Keterangan & $\%$ & Total (\%) \\
\hline 1. & Pengaruh Fasilitas Belajar (X1) terhadap Hasil Belajar IPS (Y) secara langsung & 1,66 & \\
\hline 2. & Pengaruh Fasilitas Belajar (X1) terhadap Hasil Belajar IPS (Y) melalui Motivasi Belajar (X4) & 0,24 & \\
\hline & Pengaruh langsung dan tidak langsung Fasilitas Belajar (X1) terhadap Hasil Belajar IPS (Y) & & 1,90 \\
\hline 3. & Pengaruh Minat Belajar (X2) terhadap Hasil Belajar IPS (Y) secara langsung & 2,85 & \\
\hline 4. & $\begin{array}{l}\text { Pengaruh Minat Belajar (X2) terhadap Hasil Belajar IPS (Y) melalui variabel motivasi Belajar (X4) } \\
\text { Pengaruh langsung dan tidak langsung Minat Belajar (X2) terhadap Hasil Belajar IPS (Y) }\end{array}$ & 1,07 & 3,92 \\
\hline 5. & Pengaruh Lingkungan Belajar (X3) terhadap Hasil Belajar IPS $(\mathrm{Y})$ secara langsung & 1,90 & \\
\hline 6. & $\begin{array}{l}\text { Pengaruh Lingkungan Belajar (X3) terhadap Hasil Belajar IPS (Y) melalui variabel motivasi Belajar (X4) } \\
\text { Pengaruh langsung dan tidak langsung Lingkungan Belajar (X3) terhadap Hasil Belajar IPS (Y) }\end{array}$ & 0,61 & 2,51 \\
\hline 7. & Pengaruh Motivasi Belajar (X4) terhadap Hasil Belajar IPS (Y) secara langsung & 2,43 & 2,43 \\
\hline 8. & $\begin{array}{c}\text { Pengaruh variabel-variabel lain terhadap Hasil Belajar IPS (Y) } \\
\text { TOTAL }\end{array}$ & $\begin{array}{l}89,38 \\
100\end{array}$ & $\begin{array}{c}89,38 \\
100\end{array}$ \\
\hline
\end{tabular}

Sumber: Pengolahan Data Primer

\section{Hipotesis pertama}

Nilai thitung variabel fasilitas belajar $(\mathrm{X} 1)$ sebesar 2,318. $>$ ttabel $=1,969$ pada level sig 0,021 $<\alpha=0,05$. $\mathrm{Hal}$ ini menunjukan bahwa $\mathrm{HO}$ ditolak dan $\mathrm{Ha}$ diterima artinya terdapat pengaruh yang signifikan antara fasilitas belajar dirumah (X1) terhadap motivasi belajar (X4) artinya semakin baik fasilitas belajar dirumah maka akan semakin baik pula motivasi siswa dalam belajar.

\section{Hipotesis Kedua}

Nilai thitung variabel minat belajar adalah sebesar $7,653>$ ttabel $=1,969$ pada level sig $0,000<\alpha=0,05$. $\mathrm{Hal}$ ini menunjukan bahwa $\mathrm{HO}$ ditolak dan $\mathrm{Ha}$ diterima yang berarti terdapat pengaruh yang signifikan antara variabel minat belajar (X2) terhadap motivasi belajar (X4), artinya semakin baik minat belajar siswa maka akan semakin baik pula motivasi siswa dalam belajar.

\section{Hipotesis Ketiga}

Nilai thitung variabel lingkungan belajar sebesar $5,160>$ ttabel $=1,969$ pada level sig $0,000<\alpha=0,05$. $\mathrm{Hal}$ ini menunjukan bahwa $\mathrm{HO}$ ditolak dan $\mathrm{Ha}$ diterima yang berarti terdapat pengaruh yang signifikan antara variabel lingkungan belajar (X3) terhadap motivasi belajar (X4), artinya semakin baik lingkungan belajar siswa maka akan semakin baik pula motivasi siswa dalam belajar.

\section{Hipotesis Keempat}

Nilai thitung variabel fasilitas belajar sebesar $2,063>$ ttabel $=1,969$ pada level sig 0,040 $<\alpha=0,05$. Ini berarti $\mathrm{HO}$ ditolak dan $\mathrm{Ha}$ diterima, artinya pengaruh variabel $X 1$ terhadap variabel $Y$ adalah signifikan. Ini artinya adalah Fasilitas Belajar di Rumah (X1) berpengaruh secara signifikan terhadap Hasil Belajar IPS (Y). Hasil analisis data tersebut menunjukan bahwa semakin baik fasilitas belajar di rumah maka akan semakin tinggi hasil belajar siswa pada mata pelajaran IPS.

\section{Hipotesis Kelima}

Nilai thitung variabel minat belajar sebesar 2,454 $>$ ttabel $=1,969$ pada level sig $0,015<\alpha=0,05$. Ini berarti $\mathrm{HO}$ ditolak dan $\mathrm{Ha}$ diterima, artinya pengaruh variabel $\mathrm{X} 2$ terhadap variabel $\mathrm{Y}$ adalah signifikan. Ini artinya adalah Minat Belajar (X2) berpengaruh secara signifikan terhadap Hasil Belajar IPS (Y). Hasil analisis data tersebut menunjukan bahwa semakin baik Minat Belajar siswa maka akan semakin tinggi hasil belajar siswa pada mata pelajaran IPS.

\section{Hipotesis Keenam}

Nilai thitung variabel lingkungan belajar sebesar $2,025>$ ttabel $=1,969$ pada level sig 0,044 $<\alpha=0,05$. Ini berarti $\mathrm{HO}$ ditolak dan Ha diterima, artinya pengaruh variabel $\mathrm{X} 3$ terhadap variabel $\mathrm{Y}$ adalah signifikan. Ini artinya adalah Lingkungan Belajar (X3) berpengaruh secara signifikan terhadap Hasil Belajar IPS (Y). Hasil analisis data tersebut menunjukan bahwa semakin baik lingkungan belajar siswa maka akan semakin tinggi hasil belajar siswa pada mata pelajaran IPS.

\section{Hipotesis Ketujuh}

Nilai thitung variabel motivasi belajar sebesar $2,130>$ ttabel $=1,969$ pada level sig 0,034 $<\alpha=0,05$. Ini berarti $\mathrm{HO}$ ditolak dan $\mathrm{Ha}$ diterima, ini berarti pengaruh variabel $X 4$ terhadap variabel $Y$ adalah signifikan yang artinya adalah Motivasi Belajar (X4) 
berpengaruh secara signifikan terhadap Hasil Belajar IPS (Y). Hasil analisis data tersebut menunjukan bahwa semakin baik Motivasi Belajar siswa maka akan semakin tinggi hasil belajar siswa pada mata pelajaran IPS.

\section{Pembahasan}

Pengaruh Fasilitas Belajar terhadap Motivasi Belajar siswa mata pelajaran IPS kelas XI SMK Kabupaten Tanah Datar

Penelitian ini menemukan bahwa fasilitas belajar berpengaruh secara signifikan terhadap motivasi belajar siswa mata pelajaran IPS kelas XI SMK Kabupaten Tanah Datar. Semakin baik fasilitas belajar dirumah maka akan semakin baik pula motivasi siswa dalam belajar mata pelajaran IPS. Dari analisis data dan uji hipotesis yang telah dilakukan diketahui bahwa secara parsial koefisien jalur fasilitas belajar terhadap motivasi belajar adalah sebesar 0,122 dengan t hitung $=2,318>t$ tabel $=1,969$.

Hasil penelitian sejalan dengan pendapat yang dikemukakan oleh Gie (2002:33) untuk belajar yang baik hendaknya tersedia fasilitas belajar yang memadai, antara lain ruang tempat belajar, penerangan cukup, buku-buku pegangan, dan kelengkapan peralatan. Sekolah menyediakan fasilitas yang dibutuhkan siswa dalam belajar, orang tua di rumah juga harus menyediakan fasilitas belajar anak sehari-hari. Dengan tersedianya fasilitas belajar yang memadai tersebut, diharapkan akan dapat meningkatkan motivasi siswa dalam belajar. Sehingga nantinya siswa tersebut akan dapat memperoleh hasil belajar yang baik juga.

\section{Pengaruh Minat Belajar terhadap Motivasi Belajar siswa mata pelajaran IPS kelas XI SMK Kabupaten Tanah Datar}

Penelitian ini menemukan bahwa minat belajar berpengaruh secara signifikan terhadap motivasi belajar siswa mata pelajaran IPS kelas XI SMK Kabupaten Tanah Datar. Semakin baik minat belajar siswa maka akan semakin baik pula motivasi siswa dalam belajar. Dari analisis data dan uji hipotesis yang telah dilakukan diketahui bahwa secara parsial koefisien jalur pengaruh minat belajar terhadap motivasi belajar adalah sebesar 0,406 dengan t hitung $=7,653>$ ttabel $=1,969$.

Hasil penelitian sejalan dengan pendapat Syah (2008:136) bahwa minat merupakan kecenderungan dan kegairahan yang tinggi atau keinginan yang besar terhadap sesuatu. Minat menjadi salah satu faktor internal yang mempengaruhi belajar siswa. Seorang siswa yang menaruh minat besar terhadap pelajaran, akan memusatkan perhatian lebih banyak dibandingkan siswa yang tidak memiliki minat pada mata pelajaran tersebut. Pemusatan perhatian yang intensif terhadap suatu materi memungkinkan siswa untuk belajar lebih giat.

\section{Pengaruh Lingkungan Belajar terhadap Motivasi Belajar siswa mata pelajaran IPS kelas XI SMK Kabupaten Tanah Datar}

Penelitian ini menemukan bahwa lingkungan belajar berpengaruh signifikan terhadap hasil belajar siswa mata pelajaran IPS SMK Kabupaten Tanah Datar. Semakin baik lingkungan belajar siswa maka akan semakin baik pula motivasi siswa dalam belajar. Dari analisis data dan uji hipotesis yang telah dilakukan diketahui bahwa secara parsial koefisien jalur pengaruh lingkungan belajar terhadap motivasi belajar adalah sebesar 0,286 dengan t hitung $=5,160>$ t tabel $=1,969$. Hasil penelitian ini sejalan dengan pendapat Hamalik (2001: 195) yang menyatakan bahwa lingkungan belajar adalah sesuatu yang ada di alam sekitar yang memiliki makna atau pengaruh tertentu kepada individu. Kondisi lingkungan belajar yang kondusif akan menciptakan ketenangan dan kenyamanan siswa dalam belajar, sehingga siswa akan lebih mudah untuk menguasai materi belajar secara maksimal.

\section{Pengaruh Fasilitas Belajar terhadap Hasil Belajar Siswa mata pelajaran IPS kelas XI SMK Kabupaten Tanah Datar}

Penelitian ini menemukan bahwa fasilitas belajar berpengaruh signifikan terhadap hasil belajar siswa mata pelajaran IPS SMK Kabupaten Tanah Datar. Semakin baik fasilitas belajar di rumah maka akan semakin tinggi hasil belajar siswa pada mata pelajaran IPS. Pengaruh fasilitas belajar terhadap hasil belajar siswa terlihat dengan nilai thitung 2,063 $>$ ttabel $=1,969$ pada level sig $0,040<\alpha=0,05$. Selanjutnya hasil analisis jalur menunjukan adanya pengaruh langsung fasilitas belajar terhadap hasil belajar IPS yaitu sebesar $1,66 \%$.

Temuan pada penelitian ini sejalan dengan apa yang dikemukakan oleh Ahmadi dan Supriyono (2004:88), keadaan peralatan seperti pensil, tinta, penggaris, buku tulis, buku pelajaran, jangka dan lainlain akan membentuk kelancaran dalam belajar. Kurangnya alat- alat tersebut akan menghambat kemajuan belajar anak. Jadi, jika siswa dalam belajarnya didukung dengan fasilitas belajar yang lengkap maka siswa tersebut akan lebih mudah dalam memanfaatkannya. Menurut Syah (2010: 135), salah satu faktor yang termasuk lingkungan non sosial yang mempengaruhi hasil belajar adalah fasilitas belajar.

\section{Pengaruh Minat Belajar terhadap Hasil Belajar Siswa mata pelajaran IPS kelas XI SMK Kabupaten Tanah Datar}

Penelitian ini menemukan bahwa minat belajar berpengaruh signifikan terhadap hasil belajar siswa mata pelajaran IPS SMK Kabupaten Tanah Datar. Semakin baik Minat Belajar siswa maka akan semakin tinggi hasil belajar siswa pada mata pelajaran IPS. Pengaruh minat belajar terhadap motivasi belajar siswa terlihat nilai thitung variabel minat belajar sebesar 2,454 $>$ ttabel $=1,969$ pada level sig 0,015 $<\alpha=0,05$. Selanjutnya hasil analisis jalur menunjukan adanya pengaruh langsung minat belajar terhadap hasil belajar IPS yaitu sebesar $2,85 \%$.

Hasil penelitian ini juga diperkuat dengan temuan penelitian Aritonang (2008:98) yang menyatakan bahwa faktor yang dapat meningkatkan minat dan motivasi belajar dalam memperoleh hasil belajar yang baik adalah bagaimana cara guru mengajar, karakter guru, suasana kelas yang tenang dan nyaman serta fasilitas belajar yang digunakan. 


\section{Pengaruh Lingkungan Belajar terhadap Hasil Belajar Siswa mata pelajaran IPS kelas XI SMK Kabupaten Tanah Datar}

Hasil penelitian menunjukan bahwa lingkungan belajar berpengaruh signifikan terhadap hasil belajar siswa mata pelajaran IPS SMK Kabupaten Tanah Datar. Semakin baik lingkungan belajar siswa maka akan semakin tinggi hasil belajar siswa pada mata pelajaran IPS. Pengaruh lingkungan belajar terhadap motivasi belajar siswa dapat terlihat nilai thitung variabel lingkungan belajar sebesar 2,025 > ttabel = 1,969 pada level sig $0,044<\alpha=0,05$. Hasil analisis jalur menunjukan adanya pengaruh langsung lingkungan belajar terhadap hasil belajar IPS yaitu sebesar 1,90\%.

Hasil penelitian ini mempunyai relevansi dengan pendapat yang dikemukakan oleh Pribadi (2011:29) yang menyatakan bahwa lingkungan belajar berperan sebagai pengawas yang memberikan umpan balik tentang kualitas output yang dihasilkan. Apabila output yang dihasilkan tidak sesuai dengan harapan maka sekolah perlu meningkatkan kualitas proses pendidikan dan pembelajaran yang berlangsung di dalamnya. Semakin baik lingkungan belajar maka semakin meningkat hasil belajar siswa.

\section{Pengaruh Motivasi Belajar terhadap Hasil Belajar Siswa mata pelajaran IPS kelas XI SMK Kabupaten Tanah Datar}

Hasil penelitian menunjukan bahwa motivasi belajar memilki pengaruh yang signifikan terhadap hasil belajar siswa mata pelajaran IPS kelas XI SMK Kabupaten Tanah Datar. Semakin baik Motivasi Belajar siswa maka akan semakin tinggi hasil belajar siswa pada mata pelajaran IPS. Pengaruh minat belajar terhadap motivasi belajar siswa dapat terlihat pada nilai thitung variabel motivasi belajar sebesar $2,130>$ ttabel $=1,969$ pada level sig $0,034<\alpha=0,05$. Hasil analisis jalur menunjukan adanya pengaruh langsung motivasi belajar terhadap hasil belajar yaitu sebesar 2,43\%.

Hasil penelitian ini diperkuat dengan temuan penelitian Adriani (2013) yang meneliti tentang pengaruh percaya diri, kebiasaan belajar dan motivasi belajar terhadap hasil belajar pada mata pelajaran ekonomi siswa SMA Pembangunan Laboratorium UNP. Temuan penelitiannya adalah motivasi belajar mempunyai pengaruh yang signifikan terhadap hasil belajar ekonomi siswa SMA Pembangunan Laboratorium UNP.

\section{SIMPULAN}

Berdasarkan hasil penelitian dan pengolahan data yang dilakukan pada bab sebelumnya maka dapat ditarik kesimpulan sebagai berikut:

1. Fasilitas belajar berpengaruh positif dan signifikan terhadap motivasi belajar siswa kelas XI SMK Kabupaten Tanah Datar. Artinya adalah semakin baik fasilitas belajar siswa di rumah maka akan semakin tinggi motivasi siswa dalam belajar.

2. Minat belajar berpengaruh positif dan signifikan terhadap motivasi belajar siswa kelas XI SMK Kabupaten Tanah Datar. Artinya adalah semakin baik minat belajar siswa maka akan semakin tinggi motivasi siswa dalam belajar.
3. Lingkungan belajar berpengaruh positif dan signifikan terhadap motivasi belajar siswa kelas XI SMK Kabupaten Tanah Datar. Artinya adalah semakin baik kondisi lingkungan belajar siswa dalam pembelajaran maka akan semakin tinggi motivasi siswa dalam belajar.

4. Fasilitas belajar berpengaruh positif dan signifikan terhadap hasil belajar IPS siswa kelas XI SMK Kabupaten Tanah Datar. Hal ini berarti, semakin baik fasilitas belajar siswa di rumah maka akan semakin tinggi hasil belajar IPS siswa SMK Kabupaten Tanah Datar.

5. Minat belajar berpengaruh positif dan signifikan terhadap hasil belajar IPS siswa kelas XI SMK Kabupaten Tanah Datar. Hal ini berarti, semakin baik minat belajar siswa maka akan semakin tinggi hasil belajar IPS siswa SMK Kabupaten Tanah Datar.

6. Lingkungan belajar berpengaruh positif dan signifikan terhadap hasil belajar IPS siswa kelas XI SMK Kabupaten Tanah Datar. Hal ini berarti, semakin baik lingkungan belajar maka akan semakin tinggi hasil belajar IPS siswa SMK Kabupaten Tanah Datar.

7. Motivasi belajar berpengaruh positif dan signifikan terhadap hasil belajar IPS siswa kelas XI SMK Kabupaten Tanah Datar. Hal ini berarti, semakin baik motivasi belajar maka akan semakin tinggi hasil belajar IPS siswa SMK Kabupaten Tanah Datar.

\section{DAFTAR PUSTAKA}

Adriani, Deni. 2013. "Pengaruh percaya diri, kebiasaan belajar dan motivasi belajar terhadap hasil belajar pada mata pelajaran ekonomi siswa SMA Pembangunan Laboratorium UNP". Tesis tidak diterbitkan. Padang: Program Pascasarjana UNP.

Ahmadi, Abu dan Supriyono Widodo. 2004. Psikologi Belajar. Jakarta: Rineka Cipta.

Aritonang, T. Keke. 2008. "Minat dan Motivasi dalam Meningkatkan Hasil Belajar Siswa". Jurnal Pendidikan Penabur. No.10 / Tahun ke-7 Juni.

Gie, The Liang. 2002. Cara Belajar yang Efisien. Yogyakarta: Lembaga Bina Prestasi.

Hamalik, Oemar. 2001. Pendekatan Baru Strategi Belajar Mengajar Berdasarkan CBSA. Bandung : Sinar Baru Algensindo.

Pribadi, Benny A. 2011. Model Desain Sistem Pembelajaran. Jakarta: PT.Dian Rakyat.

Purwanto, Ngalim. 2003. Psikologi Pendidikan. Jakarta: Remaja Rosda Karya.

Syah, Muhibin. 2008. Psikologi Pendidikan (Pendekatan Terbaru). Bandung: Remaja Rosda Karya. 2010. Psikologi Belajar. Jakarta: PT. Raja Grafindo Persada. 